\title{
INTELLIGIBILITY, COMPREHENSIBILITY, AND INTERPRETABILITY PROBLEMS IN THE INTERACTIONS BETWEEN LECTURERS AND STUDENTS IN ENGLISH DEPARTMENT PROGRAM
}

\author{
${ }^{1}$ Nailul Authar, ${ }^{2}$ Tatik Muflihah \\ ${ }^{1-2}$ Nahdlatul Ulama University of Surabaya \\ ${ }^{1}$ nailulauthar@unusa.ac.id, miraicha@unusa.ac.id
}

\begin{abstract}
Intelligibility, comprehensibility, and interpretability come to be problems in classroom interaction. Those 3 components contribute to flow of interaction, comprehend the message delivered, and to learning objectives attainment.This recent study was conducted by using qualitative research, in which the participants were from 2 universities with 4 different classes. then the research objectives should be constructed; to identify the intelligibility, comprehensibility, and interpretation problems in interaction between lectures and students; to investigate the extent of intelligibility,comprehensibility, and interpretation in facilitating lecturer-students communication; to depict students learning objective attainment by the practice of intelligibility, comprehensibility, and interpretation. This study using Qualitative research method. Purposes sampling was used in this study by choosing homogenous type. The data was collected through observation. Reading and analyzing references were able to sustenance the research data about the notion.This study clarified that the intelligibility, comprehensibility, and interpretability problems did not contribute significant problems to the participant due to the lecturer and the students are from same area, thus the cultural barriers were not be the core of barrier in the communication. It is more to the personal and interaction barriers of the students.
\end{abstract}

Keywords: Intelligibility, comprehensibility, interpretability, Problem, classroom interaction

Abstrak: Kecerdasan, kelengkapan, dan interpretabilitas menjadi masalah dalam interaksi di kelas. Ketiga komponen tersebut berkontribusi terhadap aliran interaksi, memahami pesan yang disampaikan, dan pencapaian tujuan pembelajaran. Penelitian terbaru ini dilakukan dengan menggunakan penelitian kualitatif, di mana para pesertanya berasal dari 2 universitas dengan 4 kelas yang berbeda. maka tujuan penelitian harus dibangun; untuk mengidentifikasi masalah kejelasan, kelengkapan, dan interpretasi dalam interaksi antara kuliah dan mahasiswa; untuk menyelidiki sejauh mana kejelasan, kelengkapan, dan interpretasi dalam memfasilitasi komunikasi dosen-mahasiswa; untuk menggambarkan siswa belajar pencapaian obyektif dengan praktik kejelasan, kelengkapan, dan interpretasi. Penelitian ini menggunakan metode penelitian kualitatif. Purposes sampling digunakan dalam penelitian ini dengan memilih jenis yang homogen. Data dikumpulkan melalui observasi. Membaca dan menganalisis referensi dapat mempertahankan data penelitian tentang gagasan tersebut. Hasil penelitian menunjukan bahwa masalah kejelasan, kelengkapan, dan interpretabilitas tidak berkontribusi masalah signifikan bagi peserta karena dosen dan mahasiswa dari daerah yang sama, sehingga budaya hambatan tidak menjadi inti dari penghalang dalam komunikasi. Ini lebih ke hambatan pribadi dan interaksi siswa.

Kata kunci: Kecerdasan, kelengkapan, interpretabilitas, Masalah, interaksi kelas

\section{INTRODUCTION}

A speaker or listener does not want to be bored with the interaction, quite the opposite, they want to be informed/or to be replied in a desired way in the shortest time possible or in the most compact, but still informative manner (Kapitonova 2016; p. 609). In any interaction, speakers speak and they listen. Exchanging messages and keeping a 
conversation flowing allows no one to be passive. Speakers interact to accomplish a purpose (or purposes). They bring with them different expectations about the way toaccomplish their goals through talk. Moreover, they have different understandings about ways to display their intentions and to give or acquire information as well as different ways to present themselves andtheir perceptions about the relationships that are present.

Academic communication between lecturers and students are mostly ensued in the classroom. Frequently discussions are about the notion of a theory; argue the implementation of the theory, or even build a conversation about educational phenomena occurred as vital and eminent issue in particular country. In a discourse process, the flow of talk and the contributions of all speakers must be considered to understand the meaning of any single utterance. As discourse emerged between people who conduct conversation, it should be meaningful and agreed by both partners; utterer and hearer. Focusing on meaningful, it is interconnection with the intelligibility occurrence in the classroom. It means that building intelligible communication needs same comprehension between them. To simply emphasized this, Nelson(1982, p. 59) in Pickering (2009, p.3)affirmed, "Being intelligible means being understood by an interlocutor at a given time in a given situation".

Problems based on the intelligibility affects to the comprehensibility and interpretation. When students have difficulty involve the intelligible communication then She or he cannot comprehend the message declared by the speaker, moreover it creates wrong interpretation. The opportunity of the emergence is not only to the concept of theory but it also happened in understanding instruction, conducting task, and grasping feedback. In which, it affects the students' attainment academically by not accomplishing the learning objectives.

Wang (2015, p. 65), he reported that college students need to develop their interpreting competence not only systematic training of interpreting skills but also sufficient authentic and deliberate practice, as well as acquisition of professional interpreting strategies and norms. He realized that by this practice students could have same perception of the lecturers in elaborating concept, material, or tasks.

This study comprised some research questions, which elaborated the subsequent problems; [1] What are the intelligibility, comprehensibility, and interpretation problems in interaction between lecturers and students? . [2] To what extent do intelligibility, comprehensibility, and interpretation facilitate lecturer-students communication?. [3] Why do intelligibility, comprehensibility, and interpretation determine the attainment of learning objective?. Since this study directed some questions to comprehend the phenomena of lecturer and students in the classroom, then the research objectives should be constructed; [1] To identify the intelligibility, comprehensibility, and interpretation problems in interaction between lectures and students. [2] To investigate the extent of intelligibility,comprehensibility, and interpretation in facilitating lecturer-students communication, [3] To depict students learning objective attainment by the practice of intelligibility, comprehensibility, and interpretation

John Levis (2011; p. 60 - 69) added that intelligibility is affected by some barriers. They comprise of the type of listening being done, the familiarity of the listener with the patterns of the speaker, the types of language features that cause conflicts with the expectations that a listener brings to the interaction, the type of speaking task.Other crucial finding of a research by a professor from Iowa University; John Levis (2011; p. 60 - 69) added that intelligibility is affected by some barriers. They comprise of the type 
of listening being done, the familiarity of the listener with the patterns of the speaker, the types of language features that cause conflicts with the expectations that a listener brings to the interaction, the type of speaking task.

Comprehensibility, on the other hand, refers to the listeners' perception of the ease or difficulty with which they can make out a speaker's meaningMunro \& Derwing, 1995; see Isaacs \& Thomson, 2013; for a discussion of scale length. Beth E. Sheppard, Nancy C. Elliott, Melissa M. Baese-Berk (2017) in their research detailed that there were some other factors beyond Jung's view about the consideration in attaining intelligibility and comprehensibility. Meanwhile, Field (2003); Jenkins (2000) defined that comprehensibility refers to context of use, a complex setting involving factors related to the speaker, the listener, the linguistic and social context, and the environment.

Smith (1992) and Pickering (2007) affirmed that interpretability is the ability of the listener to understand the speaker's intentions behind the word or utterance. Harris (1952) clarified discourse referring to analyzing "language beyond the sentence". Thus, the level of interpretation is highest above intelligibility and comprehensibility in conducting valuable interaction. Interpreting is an inter-lingual and cross-cultural activity that requires a high level of competence in multitasking in cognitive operations and immediacy in informationprocessing and transference. Interpretation entails to not only the topic that speakers and listeners discuss but correspondingly with previous knowledge related to the topic. Moreover, communicative competence includes not only the grammaticalcompetence a speaker has but the knowledge of culturally appropriate"ways of speaking," such as how to ask for information, give praise, complain, joke, and so on.

According to Liberante (2012) "the teacher-student relationship is one of the most powerful elements within the learning environment. A major factor affecting students' development, school engagement and academic motivation, teacher-student relationships form the basis of the social context in which learning takes place" (Hughes \& Chen, 2011; Roorda et al., 2011; Spilt, Koomen\& Thijs, 2011 cited by Liberante, 2012, p. 2). As Gray and Wise put it, "if we speak to someone who gives no evidence of having heard, the act of communication has not been completed; we must have knowledge that he has heard and responded in some way (1959, p. 10)".

\section{METHOD}

This study strived to recognize the interaction problem, which is grounded on intelligibility, comprehensibility, and interpretation in the classroom between lecturersstudents. As a result, this study is in line with Litosseliti (2010:52) which affirmed, "Qualitative research is concerned with structures and patterns, and how something is".

Purposes sampling was used in this study by choosing homogenous type. Homogenous sampling as Ary (2010:430)affirms that homogenous sampling selects a group that is considered homogenously in attitudes, experiences, and so on. In obtaining the sample, time, money, and effort are become consideration. In addition, Creswell (2012:208) suggests to use this procedure, because researcher need to identify the characteristics and found individuals or sites that possess it. The characteristic of the subgroup is same, especially in speaking skill, also in attitude to language. The following is the overall and general students' proficiency in language: 
Table 3.1 Students' Proficiency

\begin{tabular}{|c|c|c|c|c|c|}
\hline \multirow{2}{*}{ Items } & & \multicolumn{2}{|c|}{ Univ 1} & \multicolumn{2}{|c|}{ Univ 2} \\
\hline & & Class A & Class B & Class A & Class B \\
\hline \multirow{5}{*}{$\begin{array}{l}\text { Overall English } \\
\text { Proficiency } \\
\text { evaluation) }\end{array}$} & Levelin & & & & \\
\hline & High & 9 & 21 & 25 & 13 \\
\hline & Intermediate & 25 & 10 & 8 & 20 \\
\hline & Low & 5 & 7 & 3 & 4 \\
\hline & Frequency & & & & \\
\hline \multirow[t]{3}{*}{ Use of English } & Frequently & 5 & 18 & 7 & 5 \\
\hline & Sometimes & 13 & 9 & 11 & 17 \\
\hline & Seldom & 21 & 11 & 18 & 15 \\
\hline
\end{tabular}

The source of data to answer research question 1 in identifying the interaction problems between lectures and students are the interview result and written report about the process in teaching and learning process from the observation. Data of research question 2 in investigating the extent of intelligibility, comprehensibility, and interpretation were written and spoken document from recording the teaching and learning process.

Observation sheet and interview guide was applied to answer research question 1. The data was collected through observation. Reading and analyzing references were able to sustenance the research data about the notion. It described, analyzed, and/or evaluates information found in primary sources. Collecting and classifying proper definition of those three terms was needed to gain truthful and valid data for this study. Interview was used to strengthen the observation result. Interview conducted to students and lecturer to gather data in confirming and validating the interaction problems between lecturer and students.

Data to up hold research question 2 was gathered by conducting observation and interview. The observations of classroom interaction were detailed recorded audiovisually. It was conducted in two ways; document observation and class observation. For written document, observation focused on analyzing lesson plan, materials, slides, task, and assessment. Meanwhile, interview was utilized to clarify the consideration the lecturers had in expressing utterances, explanation, expression, and or instruction in the classroom. Last, recording lecturers-students activities in the classroom were able to investigate the phenomena and emphasized others sources of data. The recording process is collected from several meetings of four classes where the lecturers teach.

Observation was also likewise applied to resolve research question 3, in which to depict students learning objective attainment. The observation was conducted by aim to monitor the practice of intelligibility, comprehensibility, and interpretation to attain students' learning objectives. The students' successful learning was determined by how they covered the objectives and conducted those three concepts in steering communication.

\section{RESULT}

It was fond that there were several intelligibility problems blocked communication between lecturers and students. The observation result of the intelligibility problems can be seen in the following table. 
Table 4.1 The Resume Result of Intelligibility Problems in Interaction Modified from Kwaitkowski and Shriberg (1982), John Levis (2011; p. 60 - 69), andBrown (2004, p. 172-174)

\begin{tabular}{lllll}
\hline Problems & \multicolumn{2}{c}{ Univ 1 } & \multicolumn{1}{c}{ Univ 2 } \\
\hline Class A & $\begin{array}{l}\text { Class B } \\
\text { Speaking }\end{array}$ & $\begin{array}{l}\text { Class A } \\
\text { Intensive Course } \\
\text { (TOEFL) }\end{array}$ & $\begin{array}{l}\text { Class B } \\
\text { Intensive Course } \\
\text { (TOEIC) }\end{array}$ \\
\hline Grammar & $\begin{array}{l}\text { Some mistakes } \\
\text { but have grammar } \\
\text { control }\end{array}$ & $\begin{array}{l}\text { Some mistakes } \\
\text { but have } \\
\text { grammar } \\
\text { control }\end{array}$ & $\begin{array}{l}\text { Some errors but } \\
\text { have grammar } \\
\text { control }\end{array}$ & $\begin{array}{l}\text { Some errors but } \\
\text { have grammar } \\
\text { control }\end{array}$ \\
& $\begin{array}{l}\text { Fluent only in } \\
\text { particular } \\
\text { discussion }\end{array}$ & $\begin{array}{l}\text { Fluent in } \\
\text { discussing } \\
\text { particular } \\
\text { interest with } \\
\text { competence }\end{array}$ & $\begin{array}{l}\text { Fluent in all } \\
\text { conversation with } \\
\text { little mistakes }\end{array}$ & $\begin{array}{l}\text { Fluent in all } \\
\text { conversation with } \\
\text { little mistakes }\end{array}$ \\
Pronunciation & $\begin{array}{l}\text { Intelligible } \\
\text { accent though } \\
\text { often faulty }\end{array}$ & $\begin{array}{l}\text { Errors never } \\
\text { interfere the } \\
\text { understanding }\end{array}$ & $\begin{array}{l}\text { Errors never } \\
\text { interfere the } \\
\text { understanding }\end{array}$ \\
& understanding & & & \\
\hline
\end{tabular}

From the result of observation, it can be seen that there were some problems lay within the lecturer students' interaction in the classroom. The first factor that became problem in intelligibility is Grammar. Almost all students had mild grammatical problem, especially in speaking class.

Comprehensibility problems emerged in some meetings in the middle of lecturers' elaboration in the class. Interaction between lecturer and the students were observed and analyzed then the results of the problems are as follows;

Table 4.3 The Resume Result of Comprehensibility Problems in Interaction. Modified from Jung (2010)

\begin{tabular}{lllll}
\hline & Univ 1 & & Univ 2 & \\
\hline & Class A & Class B & Class A & Class B \\
\hline $\begin{array}{l}\text { Familiarity with the Topic } \\
\text { of Speech }\end{array}$ & $\begin{array}{l}\text { Not really } \\
\text { familiar with } \\
\text { the topic }\end{array}$ & $\begin{array}{l}\text { Familiar to } \\
\text { particular } \\
\text { topics }\end{array}$ & $\begin{array}{l}\text { Familiar and } \\
\text { find } \\
\text { difficulties }\end{array}$ & $\begin{array}{l}\text { Familiar and } \\
\text { find } \\
\text { difficulties }\end{array}$ \\
$\begin{array}{l}\text { Students' (as listeners) Life } \\
\begin{array}{l}\text { Experience with Non- } \\
\text { Standard Speech }\end{array}\end{array}$ & $\begin{array}{l}\text { Has } \\
\text { Experience }\end{array}$ & $\begin{array}{l}\text { Has } \\
\text { Experience }\end{array}$ & $\begin{array}{l}\text { Has } \\
\text { Experience }\end{array}$ & $\begin{array}{l}\text { Has } \\
\text { Experience }\end{array}$ \\
\hline
\end{tabular}

For achieving comprehensibility (focusing on meaning), there are several factors such as grammatical, cultural, linguistic, socio-linguistic and pragmatic aspects, as well as English Fluency. However, in this recent study not all factors as stated by Jung (2010, p. 148) were applied because some of the factors were already observed in intelligibility. Thus, comprehensibility was focusing on those aspects stated on table 4. 
Table 4.4 The Resume Result of Comprehensibility Problems in Interaction. Modified from Jung (2010)

\begin{tabular}{lllll}
\hline & Univ 1 & & Univ 2 & \\
\hline & Class A & Class B & Class A & Class B \\
\hline Listener Attitudes & Cooperative & Cooperative & Cooperative & Cooperative \\
& not active & and active & not active & and active \\
Cultural Aspects & Javanese & Javanese & Madureese & Javanese \\
Socio-linguistic aspect & $\begin{array}{l}\text { Same cultural } \\
\text { background }\end{array}$ & $\begin{array}{l}\text { Same cultural } \\
\text { background }\end{array}$ & $\begin{array}{l}\text { Same cultural } \\
\text { background }\end{array}$ & $\begin{array}{l}\text { Same cultural } \\
\text { background }\end{array}$ \\
& $\begin{array}{l}\text { Can be } \\
\text { Pragmatic aspects }\end{array}$ & Can be & Can be & Can be \\
& understood & understood & understood & understood \\
\hline
\end{tabular}

In cultural aspect, it was found that different background between the lecturers and the students were not significant. It means that they are from east Java, in which the culture is not quite different. Generally, they have same cultural background in not only habitual activities and life style but also the culture of language use. It also stated in their socio-linguistic aspect. Therefore, students did not find any difficulties when their lecturers talked and explained the material in English as they have same accent, part of speech, and the word choice were not totally different also they were able to understand the varieties of English from different cultures

Jing Ma (2013, p. 1233-1237) was used to assess the people interpretability in interaction. His concept about the interpretation procedures was applied to measure the lectures and studentsinterpretability in the classroom. There are some procedures that were observed; 1) Perception, 2) Recording, 3) Decoding, 4) Re-Expression. In perception procedure, there are 2 factors which were observed. The first is auditory perception that correlated with the students listening skills. To gain correct interpretation, listener should have good listening skills. Almost all the students have good listening skills in relation with their capability in comprehend something and get the message from the speaker speech; lecturer. While in students psychological condition result showed that in semantic class, the students felt not comfort, nervous, and worried.

In decoding procedures, students were demanded to be familiar with the lecturers dialect, pronunciation, and accent. Knowing this can help the students to be good interpreter. The students also knew and understand how to use slang words. Sometimes they brought, the slang into the class and it raise up the cheerful condition in the class.

Taking notes was accepted as the best way in interpreting message. The success of interpretation is determined largely by interpreters' comprehensive recording capability. Almost all students took note in the class while the lecture elaborated the materials. They believed that taking note helped them to memorize the message that the speaker delivered, materials. While talking about the effective mental of memorization, students also did chunking. Chunking in interpreting is a process during which interpreters actively analyze, summarize, and reorganize the messages of the speech (Jing Ma (2010, p.1235) students were actively did the chunking process in recording procedure. but the quality of the chunking result were different one to another. In the class discussion, students who had courage to ask, argue, or object were very limited. Last, the way they analyzed the material given by the lecture resulted different accuracy, and interpretation. 
The good news were even the students were fails to hear or understand certain part of information in the discourse, they tried to reconstruct by understanding the context. Students who were able to do this way means they good background knowledge and they were used to solve problem systematically. In Intensive course, the ability of conducting this problem appeared adequately. As they were learnt about the system of language, they learnt to accept and understand the conception, in which it needed the students to analyze and think how to solve the problem.

\section{DISCUSSION}

It was fond that there were several barriers blocked communication between lecturers and students. As adapted and modified from Smith (2013) "Types of Barriers in Communication",the result is elaborated as follows;

Table 4.7 Perceptual Barriers

\begin{tabular}{|c|c|c|c|c|}
\hline \multirow[t]{2}{*}{ Perceptual Barriers } & \multicolumn{2}{|c|}{ Univ 1} & \multicolumn{2}{|c|}{ Univ 2} \\
\hline & $\begin{array}{l}\text { Class A (39) } \\
\text { Semantic }\end{array}$ & $\begin{array}{l}\text { Class B (38) } \\
\text { Speaking }\end{array}$ & $\begin{array}{l}\text { Class A (36) } \\
\text { Intensive } \\
\text { Course } \\
\text { TOEIC }\end{array}$ & $\begin{array}{l}\text { Class B (37) } \\
\text { Structure } \\
\text { TOEFL }\end{array}$ \\
\hline \multicolumn{5}{|l|}{ First Impression } \\
\hline $\begin{array}{l}\text { 1. Do you know the } \\
\text { subject he/she } \\
\text { teaches? }\end{array}$ & $\begin{array}{l}\text { Yes } 23 \\
\text { No } 16\end{array}$ & $\begin{array}{l}\text { Yes } 38 \\
\text { No: } 0\end{array}$ & $\begin{array}{l}\text { Yes } 30 \\
\text { No: } 6\end{array}$ & $\begin{array}{l}\text { Yes; } 21 \\
\text { No: } 16\end{array}$ \\
\hline $\begin{array}{l}\text { 2. Do you understand / } \\
\text { can apply the } \\
\text { material? }\end{array}$ & $\begin{array}{l}\text { Yes } 15 \\
\text { No } 12 \\
\text { Somewhat } 12\end{array}$ & $\begin{array}{l}\text { Yes } 22 \\
\text { No } 7 \\
\text { Somewhat } 9\end{array}$ & $\begin{array}{l}\text { Yes } 30 \\
\text { No } 3 \\
\text { Somewhat } 3\end{array}$ & $\begin{array}{l}\text { Yes } 29 \\
\text { No } 7 \\
\text { Somewhat } 1\end{array}$ \\
\hline
\end{tabular}

The table elaborated perceptual barriers, which is consisted of 2 questions. The questions revealed the students' first impression about the subject they learnt and second, whether they understand or can apply the material. The table assumed that Semantic in class A of University 1 is as the most difficult subject for the students. It was contrary with Speaking subject in class B and Structure on TOEFL in class B of Univ 2. While English Course was subject that had the most minimum students, who said did not understand. It can be seen clearly, that students' first impression of subject they learnt did not contribute much to their comprehensibilityimmensely, as a prove, all the students declared that they know about Speaking however 7 students in the same class shown that they did not have good speaking skills.

From the students interview result, it was found that perception constructs a negative mind that impedes cognitive works. Having good perceptual had good contribution to help the students to understand the material. Other finding that supports the previous one is that students' first impression of subject participated to build good communication between lecturers and students with particular condition. Lecturers who build bonding with his/her students enhanced students to have courage in asking something they confused of. It can be seen on the following excerpt;

L : Any question?

Ss : Miss, I still confuse about the use of gerund in sentence.

SS : Yes Miss, number 13, I don't understand.

$\mathrm{L} \quad$ : Ok Ok. I will explain again 
The observation resulted that students had good relationship with their lecturer. They were not shy neither afraid to ask when they found some difficulties. This good relationship builds good communication. The astonishing finding was from their first impression about Intensive Class (TOEIC) shown that they were afraid and even some of the students were reluctant to join the class. The reasons were could be lazy, afraid because they cannot speak English, afraid with the lecturer or if they join because of formality as an obligation for their credit. Respectable communication that builds comfort with the speaker and listener enhanced the students' comprehensibility and interpretation of materials. The qualities for a positive relationship can vary to set a learning experience approachable and inviting the students to learn. Seghedin (2012), we have to admit that, not rarely, the teacher lives under the impression that his words and message get to the destination in the proper way, that they are received by the students with the exactly same meaning, the same significance which he gave them. Unfortunately, things donot alwayswork that way.

In language barriers there are 3 component observed in the classroom; linguistic difference, clarity and voice, and message delivering Students did not have any difficulty in language differences as they were from the same area, in which have same language and cultural background. Even their lecturers delivered material in English fully, it seemed they could understand especially when they were able to apply the procedure in interpretation message. Even the lecturer changed their part of speech, it did not influence anything to their comprehend as they already familiar with the lecturer speech accent. All lectures had clarity pitch of voice and talk in front of the students with medium to high voice that supported the students to get the knowledge better. Last, the message delivering process was smooth without any pressure and it made the students grasp the knowledge easily with help of the natural comprehensibility and interpretability ways toward the information they got.

There was distance between lecturer and students in semantic class. The students were afraid neither close to the lecturer; it was just a formal gap between them. Attention given to the students was normally as duty and responsibility but it was not in line with interaction between them. The lecturer - students interaction in semantic class was not warm and close. This condition was same as lecturer in university 2 in class B. both of them build relation formally between lecturer and students. both of them respect and appreciate each other but did not have warm and close interaction as lecturers of univ 1 in class B and in Univ 2 class B. Both of them were very attractive, and friendly to their students. They knew how to interact with the students and how to build communication with them. Lecture in B class of Univ 1 was even often asked to have coffee together, while the other lecture from Univ 2 was asked to hang out by their female students.

Each class has particular learning objectives and each lecturer had responsibility to make the students understand the material given by them. Semantic class had learning objectives that generally the students are able to analyze or do logical thinking of other utterances. The finding clarified that students who learnt semantic achieved the learning objectives but not significantly. It can be seen from the result of the mid test and the final test. The score they got is not the only parameter to judge the students but it could be used as a look that there was intelligibility, comprehensibility, and interpretability representative. Semantic questions in a test were open questions type, it means that the students were given opportunity to give response of cases and elaborate their answer. The point of this consideration was that the students' answers did not represent a student that has capability in doing good analysis of cases. 


\section{CONCLUSION}

The interaction problem of intelligibility, comprehensibility, and interpretability means insufficiently give impact to the attainment of learning objectives. Cultural gap will contribute problems in communication if the listener do not have adequate background knowledge of the world and of the topic discussed. The problems were tend to the personal communication barriers of the students. The students need to learnt how to communicate well to upgrade their achievement in learning.

\section{REFERENCES}

The case of Arabic-accented English. In. J. Levis \& K. LeVelle (Eds.). Proceedings of the 2nd Pronunciation in Second Language Learning and Teaching Conference, Sept. 2010. (pp. 30-42), Ames, IA: Iowa State University.

Creswell, J. W. (2012). Educational Research: Planning, Conducting and Evaluating Quantitative and Qualitative Research (Fourth ed.). Massachusetts: Pearson Education, Inc.

Dornyei, Zoltan. (2003). Questionnaires in Second Language Research: Construction, Administration, and Processing. London: Lawrence Erlbaum Associates Publishers. Proceedings of the 2nd Pronunciation in Second Language Learning and Teaching Conference, Sept. 2010. (pp. 17-29),Ames, IA: Iowa State University.

Ingred, Mathew. (2005). Errors in pronunciation of consonants by learners of English as a foreign language whose first languages are Indonesian, Gayo and Acehnese. Monash University Linguistics Papers.

Jenkins, J. (2003). World Englishes: A Resource Book for Students. New York: Routledge.

Jung, M-Y. (2010). The Intelligibility and Comprehensibility of World Englishes to Non-Native Speakers. Journal of Pan-Pacific Association of Applied Linguistics, 14(2), 141-163.

Kachru, B., Yamuna, K., and Nelson, L. (2006). The Handbook of World Englishes. USA: Blackwell Publishing Ltd.

Kachru, Y, \& Smith, Larry E. (2008). Cultures, Context, and World Englishes. New York and London: the Taylor \& Francis Group.

Kalikow DN, Stevens KN, Elliott LL. (1977). Development of a test of speech intelligibility in noise using sentence materials with controlled word predictability. J Acoust Soc Am 61 :1337-1351.

Litosseliti, Lia (Ed.). (2010). Research Method in Linguistics. New York: Continuum.

Miles, M. B., Huberman, A. M., \& Saldana, J. (2014). Qualitative Data Analysis: A Methods Sourcebook (Third ed.). Los Angeles: Sage Publications, Inc.

McMillan, J. H. (1992). Educational Research: Fundamentals for the Consumer. New York: Harper Collins. 